\title{
Tracing the theoretical path of my teaching experience at a private English institute ${ }^{1}$
}

\section{Rastreando la teoría detrás de mi experiencia docente en un instituto privado de inglés}

\author{
Angie Milena Caro Ávila ${ }^{2}$ \\ Universidad Pedagógica y Tecnológica de Colombia - Tunja \\ angiecaroavila@gmail.com
}

Received: August 31, 2017

Accepted: November 30, 2017

How to cite this article (APA, 6th ed.): Caro - Ávila, A. (2018). Tracing the theoretical path of my teaching experience at a private English institute. Enletawa Journal, 11 (1), 77-90

\begin{abstract}
This paper reflects on the connections between theory and practice in a private English institute in which students follow seven different stages to complete one lesson. The objective of the researcher, an in-service English teacher, was to analyze the institute's theoretical principles underlying each of the seven stages. These stages were studied in terms of the theories or approaches which guided the different stages in teaching and learning the English language. In order to provide an informed review of the theory and its application in practice, specialized authors, such as Richards and Rodgers (1993) or Harmer (2013), were revisited. Throughout the paper, the benefits and drawbacks students received when using the identified theories or approaches in their classes are reflected upon. Additionally, the

\footnotetext{
1 Reflective Article

2 Angie Milena Caro Ávila is a Modern Languages teacher who graduated from Universidad Pedagógica y Tecnológica de Colombia. Currently, she is studying a Masters in Language Teaching at the same university. She has worked as a full-time teacher in various private English institutes as well as teaching part-time in some universities in Tunja. Her research interests are the relationship between theory and practice, teachers' identity and intercultural practices.
} 
researcher's professional development during the steps she guided is critically analyzed.

Key words: Professional Development, Theory Practice Relationship, Language Teachers, Reflective teaching.

\section{Resumen}

El siguiente artículo presenta una reflexión sobre la conexión entre la teoría y la práctica en un instituto privado de inglés en el que los estudiantes siguen siete etapas de estudio para aprender una lección. El objetivo principal de la investigadora, una docente de inglés en servicio, fue analizar los principios teóricos que subyacen cada una de las siete etapas de estudio, mediante el análisis de las teorías y enfoques del aprendizaje y la enseñanza de inglés que guiaron la preferencia de la institución por dichas etapas para el aprendizaje del idioma. Con el fin de presentar una reflexión informada por la teoría y su aplicación en la práctica, autores especializados tales como Richards y Rodgers (1993) o Harmer (2013) son mencionados a lo largo del artículo. Las reflexiones sobre los beneficios y las desventajas que los estudiantes reciben al usar dichas teorías o enfoques en sus clases así como un análisis crítico del desarrollo profesional de la docente investigadora en los pasos dirigidos por ella van a ser discutidos a lo largo del presente artículo.

Palabras clave: Desarrollo profesional, Relación Teoría- Práctica, Docentes de Idiomas, Enseñanza Reflexiva. 


\section{Introduction}

During my experience as an inservice teacher, I have come to realize that language institutes are interesting settings worthy of being studied. This is because students undertake language courses at language institutes due to personal interests and with objectives, such as speaking the language for academic or personal purposes, travelling abroad or taking proficiency tests, among others. In this sense, language institutes face the challenge of providing high quality classes that offer students the ability to learn the language in each of the four language abilities.

Consequently, each language institute provides appealing, yet meaningful, learning methodologies that allow students to achieve their goals. These methodologies have varied in each of the institutes in which I have worked at. There are differences that range from tasks to materials, and they showcase divergent approaches to teaching and learning the language. Nonetheless, these methodologies as a whole fall under the umbrella of the communicative approach.

When recalling these experiences and reflecting about myself as a professional, I thought of teacher-self as being that of a communicative teacher. In my first job, I remember that we had to prepare students for communication with other speakers given the context and functions of the language (Canale and Swain, 1980). As soon as I left my first job, I had to adapt to a new methodology. My role as a teacher had changed, and I had to teach grammar, something which I had never done before. Consequently, I did not consider this to be part of my communicative teacher identity. Another element that I was in charge of was developing speaking activities that focused on using the language given the grammar aspects taught in the lesson. Thus, I tried to develop speaking activities that were still true to the communicative principles I considered to be valuable in teaching the language. After some time, I got used to teaching in this new environment, but I became motivated to conduct a study on whether or not the institute's methodology was valid.

The main objective of the following reflection was to identify the theoretical principles guiding the seven stages followed by the students in one lesson. I considered it fundamental to know about the theoretical principles guiding the steps established by the institute because, as Dewey (1933) stated, we need to have an "active, persistent, and careful consideration of any belief or supposed form of knowledge in light of the grounds that support it and the further consequences to which it leads" (p. 9). Dewey calls the previous process reflective action, which helps us become coherent in what we believe and what we do in the classroom.

Ur (1993) mentioned the importance of reflection and some of its elements, such as "vicarious experiences, other peoples' observations and reflection, and from other peoples' experiments, and from theories learned from research and the literature" (p. 20). Given the previous, this research was conducted in two parts. The first part was to identify some of the benefits and/or 
drawbacks of using the methodology established by the institute. This lead to the second part, in which my teacher colleagues and I took action on making the necessary changes needed to the theory-practice mismatches identified in this process. This paper focuses only on the first part of this research study. In the following pages, an individual reflection and analysis of the institute's methodology and its theories, approaches, and methods used during the steps are provided.

In order to continue discussing this topic, I will describe the terms methodology, approach and method with the help of the Dictionary of Language Teaching and Applied Linguistics by Richards and Schmidt (2010). They define methodology as "the practices and procedures used in teaching, and the principles and beliefs that underlie them" (p. 363). In this definition, we notice that methodology is a broad term concerning the beliefs we have about learning and teaching, as well as the procedures we use in order to learn or teach a language. Each teacher or institute might have a different methodology to teach a language. An approach is described as the "theory, philosophy and principles underlying a particular set of teaching practices" (p. 30). Thus, we can say that an approach is the general beliefs we have about how to learn a language. A method is "an application of views on how a language is best taught and learned and a particular theory of language and of language learning" ( $p$. 363). We note that a method is a specific set of procedures we conduct, which are coherent with our beliefs about how to learn a language.

\section{Context and participants}

The institute, which is the subject of this reflection, has many sites at the national level. It has a well-structured and fixed approach for learning English, and they describe their method as an easy and quick way to learn the language. In this paper, I intend to describe the methodology used by teachers and students, as well as some positive and negative qualities that are evident in the seven different levels of English offered. Due to the analysis of its methodology, and in order to avoid any positive or negative effects the institute might incur, its identity will remain anonymous.

The aforementioned institute is a private institution that works in a formal education capacity. This means that the Colombian Ministry of Education approves the institute's curriculum and considers it to be pedagogically suitable. A course will usually take one year to complete. However, there are other periods of completion available, such as six-month or three-month courses depending on the students' availability and preference. Students take a total of 43 modules, during which listening, speaking, reading, writing and grammar activities are combined in individual classes and activities. Due to the way the lessons are structured, being able to develop the activities plays a major role in students achieving their learning objectives. Of the 43 modules studied, 32 are structured modules and 11 are communicative modules. The purpose of this paper is to delve deeper into the 32 aforementioned modules in order to identify the different second 
language acquisition approaches and theories evident among the modules.

\section{Literature review and analysis of the institute's teaching and learning methodology}

Clarke (1994) described some of the reasons why in-service teachers could not combine theory and practice in their classes. Clarke showed how in the United States, at that time, teachers did not have control over their classes. Teaching expertise lay in the hands of the administrators and researchers of the time. Despite not being trained as teachers, administrators and researchers decided on what was correct or incorrect in teaching. In order to change this situation, scholars, such as Richards and Lockhart (1996) and Farrell (2003), motivated teachers to carry out reflections and action research in their practices in order to demonstrate that the scope of teaching is not limited to just following rules, but rather being conscious of the greater impact teaching has on society.

In Colombia, research on inservice teachers has also motivated the academic production of research and/ or action research. Cárdenas (2002); Vergara Luján, Hernández Gaviria and Cárdenas Ramos (2009) stated that research serves as a means to reflect on our practices and the settings in which we teach. Cárdenas (2002) also mentioned the importance of joining academic communities of practice, which are spaces in which we can share our experiences and practices, to learn from our stories and experiences. In the same way, Castañeda- Londoño (2017) emphasized collaboration to achieve professional development by means of peer coaching. In doing so, teachers could receive feedback from other teachers who shared the same experiences in the classroom. In this regard, it is necessary for me to share these insights with my colleagues at the institute, so that we can reflect and act towards meaningful professional development.

Connecting theory and practice is not only difficult for in-service teachers, but also for pre-service teachers. Zeichner (1983) established that the difficulty of connecting theory and practice has its roots in the undergraduate teacher formation programs. He mentioned that the practicum provided the necessary space for pre-service teachers to apply what they have learned. Nonetheless, they were not required to critically analyze the theories applied or decide upon whether their specific teaching context suited those theories, or if new theories about learning and teaching should be created. Zeichner also pointed out that there is a gap between what is taught in college and what is experienced in the classroom.

Taking into account when Zeichner's (1983) reflection was published and looking at the taxonomy of Kumaravadivelu (2003), in terms of the evolution of the paradigms used in teacher education, a connection can be made with what Kumaravadivelu called teachers as passive technicians. This refers to the perspective that teachers followed what experts in teaching told them, without any valid claims, and they were not prepared to opinionate on such matters. According to 
Kumaravadivelu (2003), three different paradigms for teacher preparation are followed. The first paradigm, teachers as passive technicians, is the oldest and least preferable paradigm as it is instructional as mentioned previously. Teachers as reflective practitioners and teachers as transformative intellectuals are the second and third stages. These stages are preferable, as teachers gain a professional position in which they can identify what is necessary or not for their context. In the latter stage, they can create their own theories on appropriate ways of teaching for the contexts in which they find themselves. Current trends in teacher preparation and professional exercise require teachers to be reflective practitioners and transformative intellectuals.

From a personal perspective, taking into account my undergraduate preparation as a language teacher, I found it difficult to connect theory and practice due to my beliefs about classrooms and what being a teacher implied. Throughout my work experience at different public schools during my teaching practicum, it was evident that the students, curriculum, and the schools themselves changed considerably. Thus, my pedagogical identity transformed according to these changes. After three years of working at different language institutes, I have come to notice that experience helps teachers decide what to do, whilst theory gives us the knowledge on what is pedagogically suitable. Despite this knowledge, we must be aware that what we do is limited by our workplace and the requirements therein, especially when we work in the private sector. Decisions on whether to use our own reflections to improve our practice must be made and communicated with other teachers, as well as the contexts where we teach. The institute, which I will describe later, allows teachers' reflections and accepts their suggestions on how to improve our practices.

Based on the previous discussion, we notice that teaching requires that teachers engage with their specific settings and analyze the elements surrounding their practice. Richards (2008) proposed to increase teachers' experience-based theory, allowing teachers to create their own thoughts on what teaching implies. Johnson and Golombek (2002) established the need for teachers to consider their experience in order to connect what they think, say, and do in the classroom. Therefore, professional development is achieved when we account for teaching, learning, reflection, creation of theories, and reasoning to support our use of action or experimental research in our classrooms (Vergara Luján, Hernández Gaviria and Cárdenas Ramos, 2009).

In order to start reflecting on the context, I clarify that professional exchange meetings at the institute are not developed on a regular basis due to time constraints. However, meetings are held once in a while to reflect on helping students communicate in the target language and developing teaching materials. Remarkably, we have never questioned whether the methodology or the students should be analyzed, or even reconsidered. We seem to accept and agree with the methodology established by the institute for learning and teaching languages. 
Teachers selected to work at the institute are prepared through an initial training, in which they receive information about the institute's methodology, their roles as teachers and the institutional expectations concerning their job. A teacher working for this institution is required to teach grammar lessons, check students' written activities, evaluate written and oral tests, and prepare communicative activities. In order to teach grammar, a standardized grammar book designed by the institute is followed. Every teacher decides on the way they want to explain a lesson, but the topics established for each of the classes cannot be changed since the curriculum is designed to follow specific developmental sequences (Cook, 2008). In her review of second language learning and teaching, Cook mentioned that developmental sequences are target language topics that are learnt in a specific order. These topics are meant to trigger meaningful learning when studied in a specific order, which ranges from easy to difficult. I analyzed the teaching cycle at the institute in order to identify the learning and teaching beliefs promoted. Even though changes cannot be made to my teaching practices, this reflection would allow me to understand how the context affects my professional identity as an English teacher.

Previously, I have defined approaches as the general beliefs we have about how to learn a language. To expand on this definition, Richards and Rodgers (1993) provided a comprehensible explanation of approaches as "theories about the nature of language and language learning that serve as the source of practices and principles in language teaching" (p. 16). Considering this definition, an approach is a term which covers a macro concept of language learning that primarily focuses on the principles of teaching and learning in order to guide teachers' decisions in the classroom.

Methods were defined as specific ways in which we carry out our teaching and learning beliefs. Regarding this, Harmer (2013) defined methods as "decisions about types of activities, roles of teachers and learners, the kinds of material which will be helpful and some model of syllabus organization" (p. 62). Based on this definition, methods are specific decisions on teaching, which are carried out by the teacher, taking the course syllabus into account. For the purposes of this research study, methods are considered more specific precepts that tend to give directions on what is suitable to use in the classroom.

In terms of the methodology used by the institute, the first step every student has to take is a module. It consists of taking an individual grammar class that lasts 45 minutes. In this step, the teacher speaks in English and/or Spanish and helps the students focus on the specific grammar topic being taught. The choice of language depends on the teacher and/or the student. Topics are organized depending on how they are arranged. This means that students study greetings and farewells before moving on to the simple present. Therefore, they study the most difficult grammar topics towards the end, which are considered to be gerunds as nouns. The curriculum delivers learning in the way that Cook (2008) or Lightbown and Spada (2013) referred to 
as developmental sequences; topics are taught progressively.

In a module or grammar lesson, students usually take notes and repeat fixed expressions used in the language, but they can also create sentences on their own using the grammar explained to them by the teacher. Teachers decide on how much interaction they want to have in the class. They are also free to decide on their own pedagogical tools such as worksheets or the lyrics of a song to teach grammar. Besides, if they wish, they can provide a summary of the grammar lesson, practice speaking in the class, or use examples from the students. The behavioristic approach is evident in this step, as learning requires "imitation, practice, reinforcement (or feedback on success) and habit formation" (Lightbown and Spada, 2013, p. 102). The teaching method that I personally use in this step suits grammar translation. According to Harmer (2013), the focus of this method is on the sentence, as students are given a grammar element to focus on and translate it from Spanish into English or vice versa. Additionally, I prefer to teach grammar interactively, which means using students' examples or responses so that they can remember what we studied in the class.

The second step is called multimedia and requires students to consolidate the grammar studied in class by studying it again in English. In order to develop this activity, students go to a multimedia room and use computers with a special software. They complete the exercises, such as fill in the gaps or rewriting sentences heard or seen before. Like the previous task, the approach used is behavioristic, as exercises require students to learn "dialogues and sentence patterns by heart" (Lightbown and Spada, 2013, p. 55). This activity is developed individually. Although a teacher is present, they only assist the student with questions related to vocabulary or grammar structures that they have not previously studied.

This stage can be considered a Computer Assisted Language Learning (henceforth CALL) tutorial. Mendieta Aguilar (2012) mentions that the CALL tutorial provides "grammar exercises of the mechanical type" (p. 166). According to Mendieta Aguilar, the CALL tutorial motivated a great amount of research to be done in lexical acquisition and pronunciation. When taking into account the face-to-face class of the first stage and the second stage of multimedia, these activities could be considered part of a blended learning course. As Mendieta Aguilar further reminds us, blended courses combine face-to-face interaction and computer practice to help us make better use of technology.

From my personal observations, I have noticed that the software used in the multimedia stage reinforces habit formation in topics such as "greetings and farewells" because basic expressions are repeated and learned by heart. The expressions are retrieved once again when developing the video activities, which is the next step after using the software. I consider that the audio-lingual method is utilized in this task since activities of this sort require students to create habits when repeating sentences. These sentences are orally presented by the teacher, 
tapes, visual aids or language labs, as Brown (1994) and Stern (1994) claimed. The software used in the institute has the characteristics of a visual grammar program (Cook and Singleton, 2014) using colors to highlight grammar variations. This step reinforces grammar correctness once again, while the students are learning.

The third step is called video. In this step, students watch audiovisual material that implicitly shows the topic and vocabulary studied, but in different scenarios. The content is complemented by a worksheet with activities, such as fill-in the gap, organizing sentences, or answering questions. The approach followed in this step is innatism, as this task helps students acquire grammatical features "when learners are engaged in meaningful use of the language" (White, 1991, as cited in Lightbown and Spada, 2013, p. 102). In this case, students internalize grammatically correct language after previous instruction in what is and is not possible to say in the language

If we consider Krashen (1985), the video activity would be part of the acquisition/learning hypothesis. In this way, acquisition takes place when listening to conversations by means of providing real input on how communication takes place, leading students to thememorization of patterns, like when a child is learning to speak. I consider that this activity also follows the audiolingual approach. Cook and Singleton (2014) mentioned a variation of audiolingualism called the audiovisual method. This method appeared in Europe and required students to watch a film, listen to a conversation, and repeat the expressions seen in it. As a follow up activity, the dialogue has exercises meant practice grammatical elements of the conversation. This resembles the task followed by the students, as they watch a video and then complete a grammar guide. This guide drills the topic(s) studied in each module. The task lasts between 45 and 90 minutes depending on the students' ability to complete the activity.

The fourth step, self-study, reinforces students listening skills, and it is expected that it also positively affects their oral skills. This task is connected to innatism as stated in Lightbown and Spada's (2013) proposal "just listen... and read" (p. 143). In this proposal, teaching is oriented towards motivating receptive skills, such as listening and reading, so that students absorb those expressions and replicate them afterwards. Once again, we can see that students receive input in listening and reading with rote repetition of sentences. Harmer (2013) reminded us that the audio-lingual approach is centered on sentence level examples, which are decontextualized from reallife. In the materials used by students, their books provide them with plenty of sentences in affirmative, negative and interrogative forms, but they are connected to independent topics instead of specific ones. Brown (1994) strengthened my opinion in considering this step as audiolingual because visual aids and listening exercises are used nonstop. The activity is completed on computers, taking from 45 to 90 minutes, so that students can move on to developing more autonomous grammar activities. 
The fifth activity is a worksheet in which students use one of their six content books to develop activities, such as writing a composition, answering questions, and reading a text. The books used by the students contain practical exercises and grammar reviews if they deem it necessary to check these concepts again. This activity is part of the cognitive approach as an "information-processing" model of learning, which is used when completing this task (Lightbown and Spada, 2013, p. 39). In this model, learners pay attention to simple forms of the language, so that when they master them, they are able to understand structures that are more complex. After studying grammar explicitly, students have what DeKeyser (2007) calls declarative knowledge, which can become procedural knowledge if it is practiced enough. According to Dekeyser, this knowledge is automatized at some point, and students cannot remember it as declarative knowledge.

I consider the worksheet stage to be derived from the audio-lingual method providing what Smith (1993) called input enhancement. Different from the study developed by White (1998), the activities in the book do not include grammar elements in bold, but rather a repetitive drill to practice the topics heard and studied previously. Each activity is developed individually, and corrections can be made using a selfreview grammar sheet. This review step is very important, as students can correct their answers with the answer key. They take notice as to why their answers are correct or incorrect. They also have the opportunity to ask the teacher for further explanations or clarifications when they cannot understand the nature of their mistakes.

Later, in the sixth step, students take a written exam, which consists of answering some questions containing the grammar topics studied previously and the main topics of the class. The clues students receive from the questions are related to Cook's (2008) developmental sequences. Similar to the previous task, students are considered to have declarative knowledge, which at this point is now procedural knowledge. This allows them to answer the questions without difficulty. To me, this is an example of what Lightbown (2008) called transfer-appropriate processing, as these grammar tests require students to complete sentences heard in a video or developed in the self-study task. Thus, they tend to be easier for students who paid attention or memorized those activities.

The approach followed in these activities would be cognitive since the students' mind is said to store, retrieve and use knowledge with the attentive ability to do so. This task is still part of the audiolingual approach. As Richards and Rodgers (1993) stated, "auraloral training is needed to provide the foundation for the development of other language skills" (p. 16). In the tests, students unscramble sentences; this activity is part of audiolingual tasks. In total, students take 32 written exams, one per topic studied. If they fail the first test of the lesson, they have to take a new test. A maximum of five tests per topic is allowed until they prove they can manage the topics studied in that lesson. 
Oral exams are the seventh step, and they are presented individually, initiating after the first two grammar lessons. Oral exams last 15 minutes, and students take 16 in total. During an exam, the teacher asks some questions based on the previous and current topics studied. For this task, a cognitive approach is followed, as the teacher and students need to interact under a modified interaction structure (Long, 1983), negotiating meaning to communicate with each other. In most cases, the teacher uses mimicry to help students understand a question, emphasizes a key word in a question, or uses synonyms for words that students do not know. As students are asked questions on the topics they have already studied, the approach would be classified as cognitive-interactionist (Ortega, 2007). This is because the questions help the teacher identify whether students have developed automatic patterns of grammar learned before. Harmer (2013) would classify this activity as part of the production stage in the Presentation, Practice, and Production audiolingual model.

Finally, in the last step students participate in a speaking club. This club is optional, and students practice two modules, which were studied beforehand in a communicative manner. Teachers plan different activities to practice the grammar embedded in these lessons, and students cannot speak Spanish. The activities are dynamic, and they include role-plays, creating stories using phrasal verbs, or giving their points of view on a controversial issue. These activities are rooted in the sociocultural approach (Vygotsky, 1978), as interaction among students is permitted in this task. Generally, students are given activities planned by the teacher but in a collaborative dialogue; groups decide which language form is useful as "it is cognitive activity and it is social activity" (Swain, 2000, as cited in Lightbown and Spada, 2013, p. 115). A communicative language teaching method is followed in this stage. Even though students have a grammar focus, free practice and creation of communicative sentences are allowed. Whenever necessary, some form of "get it right in the end" is presented (Lightbown and Spada, 2013, p. 165) since teachers recast mistakes, correct students, or ask them to rephrase what they say.

\section{Conclusions and final remarks}

It is noticeable that the institute has a variety of activities with underpinnings relying on different approaches and theories of language learning. As a whole, the methodology can be considered eclectic. This eclectic method of teaching is defined by Richards and Schmidt (2010) as "the practice of using features of several different methods in language teaching" (p. 188). The seven steps of teaching at the institute utilize a variety of different methods, such as the grammar-translation method and communicative language teaching. Predominantly, however, I identified that the cognitive approach is frequently used with an audiolingual method.

In the cognitive approach, learning is viewed as the ability to store information based on experience. 
According to Robinson and Ellis (2008), learning "involves the discovery, categorization and determination of patterns through use" (p. 109). The audiolingual method relates to the proposal "Get it right from the beginning" (Lightbown and Spada, 2013, p. 138), which suggests that language must be learnt as a specific set of grammatical features. Research reports on this method conclude that this model is the most appropriate for students who are willing to have a more traditional learning experience, as it concentrates more on grammatical accuracy than fluency. Cook (2008) mentioned that olderstudents prefer this type of method, as it provides a comprehensible way of learning structures that can be used in the language. A study undertaken by Sauvignon (1972) showed that students focusing on grammar and then on communicative activities have limited communicative ability but more accuracy in their sentences.

Students who predominantly use an audiolingual method, where a silent period is usually provided at the beginning of the course, do not develop the same communicative abilities as with other methods. In turn, this affects their fluency. This can be directly evidenced when students are asked about unfamiliar topics, and some of them struggle to provide adequate responses. Those students who augment the structured learning process provided by the institute with independent study, complemented by other learning methods, perform significantly better in these communicative tasks. Whilst the speaking clubs in the institute do provide students with a communicative focus, there is still a strong emphasis on grammar and accuracy, as well as significant teacher correction during the tasks. Therefore, this stage such cannot be considered truly communicative.

In conclusion, the methodology and approach used in the institute in the first 32 structured modules of the program provide students with the clear benefit of having a deep understanding of English grammar and the ability to produce English with minimal errors. This is best suited for students who prefer to learn in a more structured and defined way. Communicative aspects are not fully developed in these initial stages; however, they are enhanced in the remaining 11 modules, which did not form part of this study.

In terms of the pedagogical experience I have gained from this context, I have seen how I have adopted a more grammar-oriented approach when teaching English. In order to help students understand some of the grammar aspects of the language, I have used Spanish to provide a contrastive analysis with some aspects of English grammar. This experience has been very interesting because I used to work in a communicative institute before, and I noticed that I focused more on promoting interaction in the class more than grammar accuracy. Now, I care about helping my students understand the grammatical aspects of the language in the module step, which is the one oriented by teachers. In other activities which are oriented towards communication, I also focus on grammar, such as the speaking clubs and oral exams. These activities relate more to grading students' performance. Through this teaching experience, 
grammar has slowly become a much more intrinsic aspect of my teaching practices, and my beliefs about its importance have been notably altered. This influence can be seen in the grading system that I use at work when listening to students' performance and delivering the modules designed by the institution. Interestingly, this effect has not been limited to this institute, but has also affected my teaching practices in the two universities where I also teach.

\section{References}

Brown, H. (1994). Teaching by principles an interactive approach to language pedagogy. New Jersey: Prentice Hall Regents.

Canale, M., and Swain, M. (1980). Theoretical bases of communicative approaches to second language teaching and testing. Applied linguistics, 1(1), 1-47.

Cárdenas, M. L. (2002). Teacher research as a means to create teachers' communities in inservice programs. HOW, 9(2), 1-6.

Castañeda-Londoño, A. (2017). Exploring English teachers' perceptions about peer-coaching as a professional development activity of knowledge construction. HOW, 24(2), 80-101.

Clarke, M. A. (1994). The dysfunctions of the theory/practice discourse. TESOL Quarterly, 9-26.
Cook, V. (2008). Second language learning and language teaching. London: Hodder Education.

Cook, V., and Singleton, D. (2014). Key topics in second language acquisition. Bristol: Multilingual Matters.

DeKeyser, R. (2007). Skill acquisition theory. Theories in second language acquisition: An introduction. Retrieved from https://onlinelibrary.wiley. c o m / d o i / p d f / $10.1002 / 9781405198431$. wbeal0311

Dewey, J. (1933). How we think. Wisconsin: University of Wisconsin Press.

Farrell, T. (1998). Reflective teaching: The principles and practices. Forum, 36(4), 4.

Harmer, J. (2013). The practice of English language teaching (4th ed.). Harlow: Longman.

Johnson, K., and Golombek, P. (2002). Teachers' narrative inquiry as professional development. London: Cambridge University Press.

Krashen, S. (1982). Child-adult differences in second language acquisition. Series on issues in second language research. Newbury: House Publishers, Inc.

Krashen, S. (1985). The input hypothesis: Issues and implications. London: Addison-Wesley Longman Ltd. 
Kumaravadivelu, B. (2003). Beyond methods: Macrostrategies for language teaching. Yale: Yale University Press.

Lightbown, P. M. (2008). Transfer appropriate processing as a model for classroom second language acquisition. Understanding Second Language Process, 27-44.

Lightbown, P. and Spada, N. (2013). How languages are learned (4th ed.). Oxford: Oxford University Press.

Long, M. (1983). Native speaker/nonnative speaker conversation and the negotiation of comprehensible input. Applied linguistics, 4(2), 126-141.

Mendieta-Aguilar, J. A. (2012). Blended learning and the language teacher: A literature review. Colombian Applied Linguistics Journal, 14(2), 163-180.

Ortega, L. (2007). Meaningful L2 practice in foreign language classrooms: A cognitive-interactionist SLA perspective. Practice in a second language: Perspectives from applied linguistics and cognitive psychology, 180-207.

Richards, J. C. (2008). Second language teacher education today. RELC journal, 39(2), 158-177.

Richards, J. C., and Lockhart, C. (1996). Reflective teaching in second language classrooms. Cambridge: Cambridge University Press.
Richards, J., and Rodgers, T. (1993). Approaches and methods in language teaching (9th ed.). Cambridge: Cambridge University Press.

Richards, J. C., and Schmidt, R. W. (2010). Longman dictionary of language teaching and applied linguistics. New York: Routledge.

Smith, M. S. (1993). Input enhancement in instructed SLA: Theoretical bases. Studies in second language acquisition, 15(2), 165-179.

Stern, H. H. (1994). Fundamental concepts of language teaching (8th ed.). Oxford: Oxford University Press.

Ur, P. (1993). Teacher learning. ELT Journal, 46(1), 56-61.

Vergara Luján, O., Hernández Gaviria, F., and Cárdenas Ramos, R. (2009). Classroom research and professional development. Profile Issues in Teachers Professional Development, (11), 169-192.

Vygostky, L. (1978). Mind in society, the development of higher psychological processes. Cambridge: Harvard University Press.

White, J. (1998). Getting the learners' attention: A typographical input enhancement study. Focus on Form in Classroom Second Language Acquisition, 85-113.

Zeichner, K. M. (1983). Alternative paradigms of teacher education. Journal of Teacher Education, 34(3), 3-9. 